Review

\title{
EVALUATION OF MEAT USED FOR HUMAN CONSUMPTION IN LATVIA
}

\author{
Aleksandrs Jemeḷjanovs, Inese Zïtare, Ināra Helēna Konošonoka, Vera Krastina, \\ Liga Proškina, Imants Jansons, and Vita Strazdiṇa
}

Research Institute of Biotechnology and Veterinary Medicine "Sigra", Latvia University of Agriculture, Institūta iela 1, Sigulda, LV-2150, LATVIA

sigra@lis.Iv

Contributed by Aleksandrs Jemeḷjanovs

\begin{abstract}
Over the last decade in Latvia, the production levels of beef, pork and poultry meat have been dramatically reduced. The yearly meat consumption per capita in Latvia is about $60 \mathrm{~kg}$. Traditionally, pig meat consumption is higher than consumption of bovine meat, which has higher production costs. Lower priced meat from European countries is imported and placed on the market in Latvia. The Research Institute of Biotechnology and Veterinary Medicine "Sigra", Latvia, LUA, performs important research on meat quality and acquisition of safe and healthy food of animal origin. Cattle herds of meat breed are highly varied both from the aspect of animals and the quality of the sold meat produce. In meat of bovine animals, the settling of cholesterol on the blood vessel walls is precluded by 5.4-8.13\% $\omega-3$ and $12.97-16.27 \% \omega-6$ on average. The meat of the beef breed cattle contains wholesome proportions of proteins, fatty acids in quantities sufficient for humans, a relatively low cholesterol level (about $77 \mathrm{mg} \%$ ) and good qualities of the culinary flavours and aromas. There are on-going research studies on the quality of meat of different pig breeds and their influencing factors, as well as on acquisition of meet in accordance with the consumer requirements. Extensive research is carried out also on the quality of broiler meat, with the target of acquisition of new quality meat. Assessment of the role of game meat in human consumption and the hygiene aspects of its acquisition are also included. Due to the development of heliculture in Latvia, the assessment of snail meat and its role in human consumption has also been launched.
\end{abstract}

Key words: meat, meat production, quality.

\section{MEAT PRODUCTION AND CONSUMPTION IN THE EUROPEAN UNION}

The Europe Union meat sector was supported by a relatively strong level of demand on the world market in 2011 characterized by the quite favourable global economic situation. Global import demand increased, partly as a consequence of animal disease related supply constraints in the Far-East. Overall supply of meat was further constrained by high feed costs despite the reasonably good harvest in the EU, US, Canada and Russia. As a consequence, world prices increased, which contributed to the continued good performance of EU exports.

As domestic consumption slackened, EU beef supply temporarily outpaced the demand in 2010 . This resulted in private stock building and increased the availability for exports during the last part of the years 2010 and 2011. As beef prices in South America rose, Russia increasingly sourced from the EU. The import supply of beef, historically predominantly sourced from South America, remains limited.
Higher domestic beef prices, in combination with the economic recession, reduced EU beef sales. The countries which have been hit the most by the financial crisis, namely, Greece, Spain and Portugal, reported the most pronounced cuts in beef consumption during 2010. But also in France, the United Kingdom and Germany, beef consumption is on the decline. Another factor behind the falling beef consumption is the increasing popularity of broiler meat due to its lower price, perceived health advantages and convenience (Anonymous, 2012b).

The production of beef in the EU continues to be influenced by quantitative restrictions on milk production, given increasing yields per cow. In April 2011, the European beef forecasting meeting put beef production by $10 \%$ lower than in 2010, with a further decline of $1 \%$ expected in 2012 (Anonymous, 2011a).

With beef consumption declining only by $1 \%$ despite the scale of the euro zone crisis, in a context of high global beef prices and tight supplies, the underlying EU supply and de- 
mand situation supported a strong increase in EU beef prices. December 2011 saw a fourth month of record EU beef prices ( $€ 380 / 100-\mathrm{kg}$ carcass weight), and over 2011 average EU beef prices rose by $9 \%$, but with variations between member states. In the market of greatest interest to ACP beef exporters - the UK - prices rose by $20 \%$. Strong EU beef prices are expected to continue into 2012.

As for the EU beef sector, the reduction of cattle herds continued in 2011 ( $-2.3 \%$ as compared to 2010). The number of cows were decreased, particularly in Romania $(-17.5 \%)$ and Italy $(-6.3 \%)$. The situation in the dairy market contributed to this drop in the overall cattle herd. According to more recent forecasts, EU beef and veal production would increase by $1.8 \%$ in 2011 .

In beef trade with third countries the EU maintains its position as net exporter in volume. The main driver has been the firm demand from Russia and particularly the emergence of the Turkish market following the lowering of prohibitive tariffs at the end of 2010. Afterwards, the Turkish government has raised import tariffs for red meat to $75 \%$ in July 2011 to encourage imports of live cattle rather than beef.

Beef meat imports into the EU were $10 \%$ lower than in 2010, since shipments from both South America and Africa declined as a result of lower production from main supplying countries and the ban of imports from Botswana. USA and Australian beef exports to the EU continue to rise since the creation of a new duty-free quota for high quality beef. Further growth can be expected also from Canada, Uruguay and New Zealand that can also export with this quota. Beef meat exports would have increased by over $30 \%$ due to the low global availability, which led to an increasing demand for relatively high priced EU beef on the global markets. Exports to Turkey tripled for beef meat and increased fivefold in live animals (Anonymous, 2011a). The overall EU beef and veal consumption in 2011 is expected to remain at the same level than 2010, with a per capita consumption at $16.2 \mathrm{~kg}$ (Anonymous, 2012a).

As far as the EU pig sector is concerned, high prices until the end of 2011 and cereal prices coming down have brought back the theoretical producer margins to the 5-year average. The sector is facing a continuing process of concentration to larger production units. The sow herd slightly reduced. Nevertheless, the increasing trend in production continued in 2011 , and the total production grew by $1.7 \%$.

As regards exports, 2011 was an exceptional year. For the first time in its history, the EU exported more than 3 million tonnes of pig meat, an increase of over $20 \%$ against 2010 and representing nearly $12 \%$ of the domestic production. Hong Kong and China became the first export destination (30\% of EU pig meat exports), followed by Russia (27\%). Pig meat imports into the EU further decreased to $36000 \mathrm{t}$ in $2011,13 \%$ down compared to 2010. Switzerland remained the main origin accounting for almost half of all EU imports. Pig meat consumption is estimated to remain stable in 2011, whereas the per capita consumption would fall to $41.2 \mathrm{~kg}$ (Anonymous, 2012a).

Poultry meat is the second most important among meat species in the EU today. The European annual gross production is 11.8 million tonnes and the consumption equals about 23.3 kilogrammes per capita per year 2009 while the total meat consumption in the EU has been negatively affected by the economic recession. Poultry meat, which is the cheapest source of animal protein, was less affected. The total poultry meat consumption has increased from 10.3 million tonnes in 2004 to 11.6 million tonnes in 2009 . The consumption growth was slower than the population increase, showing that consumption is slightly decreasing per capita (Magdelaine et al., 2008). The consumption per head was high in Spain, the United Kingdom (UK), Denmark, and relatively low in Germany and Italy. For the EU, the production and consumption is almost in balance. In 2009, the EU gross production was 11803 million tones and the consumption was 11630 million tonnes (self-sufficiency rate of $100.8 \%)$.

The EU poultry meat exports increase gradually over the medium term by $2.5 \%$ in 2009 compared with 2008. In 2009 , the EU poultry meat import has decreased by $1.9 \%$ compared with 2008. Some countries, like the Netherlands, France, Belgium-Luxembourg, Poland, and Hungary, are at the same time importing and exporting poultry meat. France is the only country exporting large amounts of poultry meat to the third countries. The Netherlands were mainly exporting fresh poultry meat to Germany and the UK. The EU poultry meat self-sufficiency level increased by $0.4 \%$ in 2009 , but had decreased by $4.9 \%$ compared with 2004 (Anonymous, 2012b).

The dominant production of chicken meat production (tonnes) of total poultry meat production is coming from the UK - 1.46 million tonnes, Spain -1.17 million tonnes, and Poland - 1.06 million tonnes. In 2009, the level of self-sufficiency in the EU was $100 \%$. Within this, there are significant country variations among the Netherlands (188\%). Belgium-Luxembourg (165\%), Hungary (124\%), France (120\%), and Poland (118\%). The self-sufficiency levels in Latvia were $49 \%$ and Lithuania - 80\%, which is by 31 percentage points more in comparison with Latvia. In Latvia, Estonia, and other EU countries, production of chicken meat in general statistics is not separated from the total numbers of poultry meat production.

\section{MEAT CONSUMPTION AND PROBLEMS IN THE BALTIC REGION}

Total poultry meat production in the Baltic States has been increasing since 2004, the largest meat producer being Lithuania. Production of poultry meat in the Baltic States from 82359 tonnes in 2004 has increased to 109487 tonnes in 2009 , thus, increasing by $32.9 \%$. Total poultry meat produced in Lithuania amounted to 71437 tonnes $(65.2 \%$ of the total poultry meat in the Baltic States), followed by Lat- 
via - 23168 tonnes (21.2\%), and Estonia - 14882 tonnes $(13.6 \%)$ in 2009 . Poultry meat consumption in the Baltic States was $20.6 \mathrm{~kg}$ per capita on average but it is $20.2 \mathrm{~kg}$ per capita in Latvia and in Estonia - $18.8 \mathrm{~kg}$ per capita, and in Lithuania - $22.7 \mathrm{~kg}$ per capita (Anonymous, 2010; 2011b).

Over the last 20 years, agricultural production, including meat production, has experienced a swift decline in the Baltic States. Regarding the production volumes of pork, beef and poultry meat in the region, the highest reduction has taken place in Latvia.

According to data provided by Latvian State Institute of Agrarian Economy (LSIAE), the proportion of beef meat in the structure of end products sourced from Latvian agriculture is $5 \%$, pork $-8 \%$ and poultry meat $-4 \%$.

In Latvia, about $60 \mathrm{~kg}$ meat per capita is consumed per year, including pork, beef and poultry meat (Table 1). Traditionally, pork is preferred to other kinds of meat. Its popularity being underpinned not only by tradition but also by the price of beef, which is currently higher. The consumption of beef per capita per year has remained at the level 7-8 kg, which compared to that in the European Union (EU) Member States is ten times lower. Beef consumption is influenced also by the economic conditions of the country and competition from lower-priced kinds of meat.

Table 1

MEAT CONSUMPTION AND SELF-SUFFICIENCY OF MEAT IN LATVIA IN 2010

\begin{tabular}{l|c|c|c}
\hline \multicolumn{1}{c}{ Type of meat } & $\begin{array}{c}\text { Produced, } \\
\text { thousand t }\end{array}$ & $\begin{array}{c}\text { Consumed, } \\
\text { thousand t }\end{array}$ & $\begin{array}{c}\text { Self-sufficiency, } \\
\%\end{array}$ \\
\hline Pork & 37.2 & 67.0 & 55.0 \\
Poultry meat & 23.5 & 44.0 & 55.0 \\
Beef & 18.4 & 11.0 & 59.0
\end{tabular}

Source: Central Statistics Bureau

Lower-priced meat marketed in Latvia is imported from the Member States of the EU. The overall production costs for Latvian farmers are higher due to the lowest level of direct payments they receive in the whole of the EU. Given the transportation conditions and delivery terms, imported meat does not always meet the highest quality requirements. Apart from the traditionally consumed meats of agricultural animals in Latvia, an important role is played also by the game meat.

\section{MEAT QUALITY AND ITS MEANING IN FOOD}

Meat for human consumption is one of the main sources of protein, amino acids, fatty acids, minerals and vitamins. The quality of meat is characterised by its chemical composition (Table 2).

The volume and proportions of different types of tissue in carcasses of different species of animals are diverse (Table
3). Depending on age, sex, body condition and other factors, muscle tissue, adipose tissue, connective tissue and bone tissue ratio may vary in a wide range, both among species and among meat of different animals of the same species.

Muscle tissue, which constitutes $60-70 \%$ of the weight of beef carcass, is an indicator that is characteristic of the nutritional value of beef. Its main ingredient is high-value proteins. According to data of the Research Institute of Biotechnology and Veterinary Medicine Sigra, LUA, meat of beef breeds consists of $19-23 \%$ protein, $0.9-1 \%$ fat and $71-77 \%$ water on average. These indicators are optimum proportions for favourable impact on metabolic processes and health of humans. Beef is a dietary high quality product, especially advisable for individuals subject to iron deficit, as iron compounds consumed with meat are highly available to the organism. The iron content in veal (2.5-2.7 $\mathrm{mg} \%)$ is higher than in pork (1.0-1.3 $\mathrm{mg} \%)$, and therefore, veal is recommended also for infant food. The composition of amino acids in meat protein is highly varied. Muscle proteins contain all essential amino acids. Their composition depends on the species, breed, and age and body condition of animals.

The amount of body fat varies in relation to genetic origin and body condition of animals. From the aspect of caloric value, there is little difference between subcutaneous and intramuscular types of fat; but higher importance is attached

Table 2

CHEMICAL COMPOSITION AND ENERGY VALUE OF MEAT SOURCED FROM DIFFERENT SPECIES OF ANIMALS

\begin{tabular}{l|c|c|c|c|c}
\hline \multicolumn{1}{c|}{ Indicators } & $\begin{array}{c}\text { Water, } \\
\%\end{array}$ & $\begin{array}{c}\text { Protein, } \\
\%\end{array}$ & $\begin{array}{c}\text { Crude fat, } \\
\%\end{array}$ & $\begin{array}{c}\text { Cholesterol, } \\
\mathrm{mg} \%\end{array}$ & $\begin{array}{c}\text { Energy } \\
\text { value, } \\
\mathrm{kcal} / 100 \mathrm{~g}\end{array}$ \\
\hline Beef & $71-77$ & $19.0-23.0$ & $0.9-1.0$ & 77 & 140 \\
Venison & $73-77$ & $20.0-24.0$ & $0.5-2.1$ & 44 & 100 \\
Roe-deer meat & $72-76$ & $19.0-24.0$ & $0.9-2.4$ & 43 & 105 \\
Pork & $80-82$ & $15.5-18.5$ & $2.5-3.0$ & 82 & 160 \\
Broiler meat & $60-64$ & $20.0-22.0$ & $1.5-1.9$ & 64 & 107 \\
Snail meat* & 86.3 & 13.00 & 1.8 & 145.2 & 53.2
\end{tabular}

Data source: Research Institute of Biotechnology and Veterinary Medicine "Sigr", Latvian University of Agriculture (Jemeljanovs et al., 2009; Strazdina et al., 2010; Vitina et al., 2010; Jemeljanovs et al., 2010; Gramatina et al., 2011; Strazdina et al., 2011; Cerina et al., 2011; Jansons et al., 2011; Strazdina et al., 2012); *unpublished data

Table 3

TISSUE PROPORTIONS IN CUT CARCASSES FOR ANIMALS OF DIFFERENT SPECIES, \%

\begin{tabular}{lcccc}
\hline \multicolumn{1}{c}{ Type of tissue } & Beef & Pork & Mutton \\
\hline Muscle tissue & $57-62$ & $39-58$ & $49-56$ \\
Adipose tissue & $3-16$ & $15-45$ & $4-18$ \\
Connective tissue & $9-12$ & $6-8$ & $7-11$ \\
Bone and cartilage tissue & $17-29$ & $10-18$ & $20-35$ \\
Blood & $0.8-1.0$ & $0.6-0.8$ & $0.8-1.0$
\end{tabular}

Source: Zariņš and Neimane, 2002 
to intramuscular fat. This type of fat imparts juiciness and aroma to meat during processing, as extractives are mainly deposited there.

Intramuscular fat contains less saturated fatty acids, and more valuable unsaturated fatty acids (linoleic acid $\omega-6$, linolenic acid $\omega-3$ and arachidonic acid). Unsaturated fatty acids participate in metabolic processes and favourably influence the human organism. They are not produced by the human body, and therefore, have to be consumed through food.

Beef contains on average $5.4-8.13 \% \mathrm{w}-3$ and $12.97-$ $16.27 \% \omega-6$. Both fatty acids preclude the selling of cholesterol on walls of blood vessels. At the same time, beef contains about $77 \mathrm{mg} \%$ cholesterol. It should be noted that beef breed cattle has a lower cholesterol level than that of dairy breeds. Meat of the beef breed bovines contains a large number of wholesome proteins and fatty acids that are present in quantities and proportions appropriate for human, the meat has a relatively low cholesterol level, and has good culinary qualities of taste and flavour.

The Research Institute of Biotechnology and Veterinary Medicine "Sigra" of Latvia University of Agriculture is involved in continuous research and practical work in the field of muscle quality, amino acid proportions and intramuscular fat of meat obtained from beef breed animals.

Comparison of different species showed that the proportion of adipose tissue in pig carcass was higher than that of the muscle tissue. According to the nutrition scientists, the traditional pork quality indicators are its protein, fat and mineral content as well as the energy value. In comparison with the chemical composition of beef muscle tissue, pork has higher energy value and fat content (Table 4).

For animals having good body condition score, the total amount of proteins and fats is higher than for animals of a poor body condition score. Muscle tissue and adipose tissue have higher nutritional value. Meat quality is affected by amounts of the amino acids tryptophan and oxiproline and their ratio (Table 5). The tryptophan/oxiproline ratio in pork is higher (7.2) than in beef (3-4), indicating a relatively higher nutritive value.

With animal body condition is lower, the tryptophan/oxyproline ratio and the amount of intramuscular fat is reduced in muscle tissue, while the amount of connective tissue protein, namely oxyproline, increases. A more intensive meat colour and higher water retention are characteristic of muscular tissue with higher content of intramuscular fat.

A significant correlation exists between oxyproline concentration and amount of intramuscular fat. Pigs with higher slaughter weight have higher amounts of intramuscular fat ( $\mathrm{r}=0.52 ; P<0.001)$. An increase of amount of intramuscular fat is associated with an increase of the oxyproline level $(\mathrm{r}=0.33 ; P<0.01)$. It can be assumed that increase of intramuscular fat is associated with increased formation of connective tissue in the muscle tissue, due to the relation-
Table 4

CHEMICAL COMPOSITION AND ENERGY VALUE OF MEAT

\begin{tabular}{l|c|c|c|c|c}
\hline Product & $\begin{array}{c}\text { Water, } \\
\%\end{array}$ & $\begin{array}{c}\text { Proteins, } \\
\%\end{array}$ & $\begin{array}{c}\text { Fat, } \\
\%\end{array}$ & $\begin{array}{c}\text { Ash, } \\
\%\end{array}$ & $\begin{array}{c}\text { Energy } \\
\text { value, } \\
100 \mathrm{~g}, \mathrm{KJ}\end{array}$ \\
\hline \multicolumn{6}{c}{ Beef } \\
Category 1 & 67.7 & 18.9 & 12.4 & 1.0 & 782 \\
Category 2 & 71.7 & 20.2 & 7.0 & 1.1 & 602 \\
Bacon & 54.8 & 16.4 & 27.8 & 1.0 & 1322
\end{tabular}

Source: Zariņš and Neimane, 2002

Table 5

AMINO ACID CONTENT IN PORK

\begin{tabular}{l|c|c}
\hline \multirow{2}{*}{ Indicator } & \multicolumn{2}{c}{ Pork } \\
\cline { 2 - 3 } & $\begin{array}{c}\text { muscle } \\
\text { tissue }\end{array}$ & $\begin{array}{c}\text { adipose } \\
\text { tissue }\end{array}$ \\
\hline Water,\% & 74.6 & 38.4 \\
Protein,\% & 20.4 & 11.7 \\
Essential amino acids, mg 100g; incl: & 7801 & 4605 \\
$\quad$ Lysine & 1631 & 963 \\
$\quad$ Methionine & 478 & 286 \\
$\quad$ Tryptophan & 274 & 154 \\
Non-essential amino acids, mg 100g; incl. & 11637 & 7068 \\
$\quad$ Oxipiroline & 50 & 150 \\
Total amino acids, mg 100g & 19438 & 11673
\end{tabular}

Source: Jemeljanovs, 1999

ship with oxyproline (Ramiņš, 1999). The presence of adipose tissue in pork ensures its energy or caloric value, makes it more tender and adds flavour, while an excess proportion of fat in meat reduces its protein content and thus decreasing the nutritive value of the product. Subcutaneous adipose tissue contains $92-94 \%$ fat, $4.0-4.5 \%$ water and $1.3-1.5 \%$ of stroma. The biological value of intramuscular and subcutaneous fat increase with raised levels of essential poly-unsaturated fatty acids, especially $\omega-3 \omega-6$. The fatty acid content of the adipose tissue of pigs in muscle tissue and lipids is reflected in Table 6. The larger part of fatty acids, by analogy with adipose tissue lipids, are: oleic acid, palmitic acid, stearic acid, palmitoleic acid and myristoleic acid (Jemeljanovs, 1999).

The relationship between the amount of intramuscular fat and the organoleptic quality of meat is associated with many factors, including the pig breed. Djuroc breed pigs have a higher amount of intramuscular fat $(2.2 \%)$, and hence a better taste quality. Pjetren breed pigs, on the other hand, tend to have lower levels of intramuscular fat; and accordingly their meat has poorer taste quality (Warris et al., 1990; Warris, 2000).

The recommended minimum amount of intramuscular fat at optimum pig meat fibrousness is 2.5-3.0\% . Danish scientists indicate that $2 \%$ is the optimum amount of intramuscular fat for good taste characteristics. An increase of live 
LIPID CONTENT IN PORK*

\begin{tabular}{ccc}
\hline Indicators & In muscle tissue & In adipose tissue \\
\hline Total lipids \%: & 3.50 & 91 \\
Triglycerides, \% & 2.80 & 89.6 \\
Phospholipids, \% & 0.64 & 1.23 \\
Cholesterol, mg\% & 0.06 & 0.09 \\
Fatty acid \% of total lipids: & 3.18 & 86.7 \\
Total saturated fatty acids & 1.23 & 33.34 \\
Myristoleic acid & 0.05 & 1.21 \\
Pentadecanoic acid & 0.01 & 0.05 \\
Palmitic acid & 0.79 & 20.64 \\
Heptadecanoic acid & 0.01 & 0.33 \\
Stearic acid & 0.37 & 11.00 \\
Total monounsaturated fatty acids & 1.63 & 41.90 \\
Myristoleic acid & 0.06 & 0.03 \\
Palmitoleic acid & 0.12 & 3.12 \\
Oleic acid & 1.45 & 38.70 \\
Total poly-unsaturated fatty acids & 0.32 & 10.41 \\
Linoleic acid, $\omega-6$ & 0.24 & 9.45 \\
Linolenic acid, $\omega-3$ & 0.04 & 0.61 \\
Arachidonic acid & 0.04 & 0.35 \\
\hline
\end{tabular}

* Pork is differentiated from beef by a higher amount of poly-unsaturated fatty acids.

Source: Jemeljanovs, 1999.

weight and muscle is followed by a decrease in muscle protein value, while increase of intramuscular fat causes improvement of the organoleptic qualities or "eating quality of meat", which can be named also the dietetic quality. Fatfree meat has a neutral taste, and hence it is tasteless.

Meat quality is influenced by environmental conditions. High instantaneous stress before slaughter causes a very rapid decrease of $\mathrm{pH}$ in pigs, thus impairing meat quality and causing a muscle tissue condition labelled PSE, when meat is rendered pale in colour, soft and watery. Long-term stress, on the other hand, causes pig meat to become darkcoloured, hard and dry (DFD) (Jansons and Jemeljanovs, 2010).

High quality and healthy broiler meat is characterised by a high content of poly-unsaturated fatty acids (omega- 6 and omega-3), vitamins and minerals, and a low level of saturated fatty acids and cholesterol. Therefore, rather than increasing the quantity of obtained meat, the goal of broiler meat production is to increase the production of quality broiler meat. Broiler meat of high quality, which is wholesome for human consumption, contains biologically active substances that have favourable impact on functions of the human system, reduce risk factors of various diseases and support human health. One of the high risk factors capable of promoting deterioration of health is deficit of omega group fatty acids (linolenic acid $\omega-3$ and linoleic acid $\omega-6$ ) in ordinary food products. Consumption of omega group fatty acids with foodstuffs promotes cholesterol metabolism in humans and precludes the risk factors causing cardiovascular and other disease. (Fig. 1)

To obtain higher quality and wholesome broiler meat with increased content of fatty acids - linolenic acid ( $\omega-3)$ and linoleic acid ( $\omega-6)$ — we carried out feeding trials for broilers where the test group received combinations of soya, rapeseed and linseed oil with different omega-3 and omega-6 fatty acid content and their ratio (Table 7).

The amount of fatty acids and cholesterol in broiler meat as well as production were influenced by fatty acid composition and ratio in feed. It was established that the highest level of linolenic acid in meat (13.0\%) was reached by adding the following combination of vegetable oils to the feed

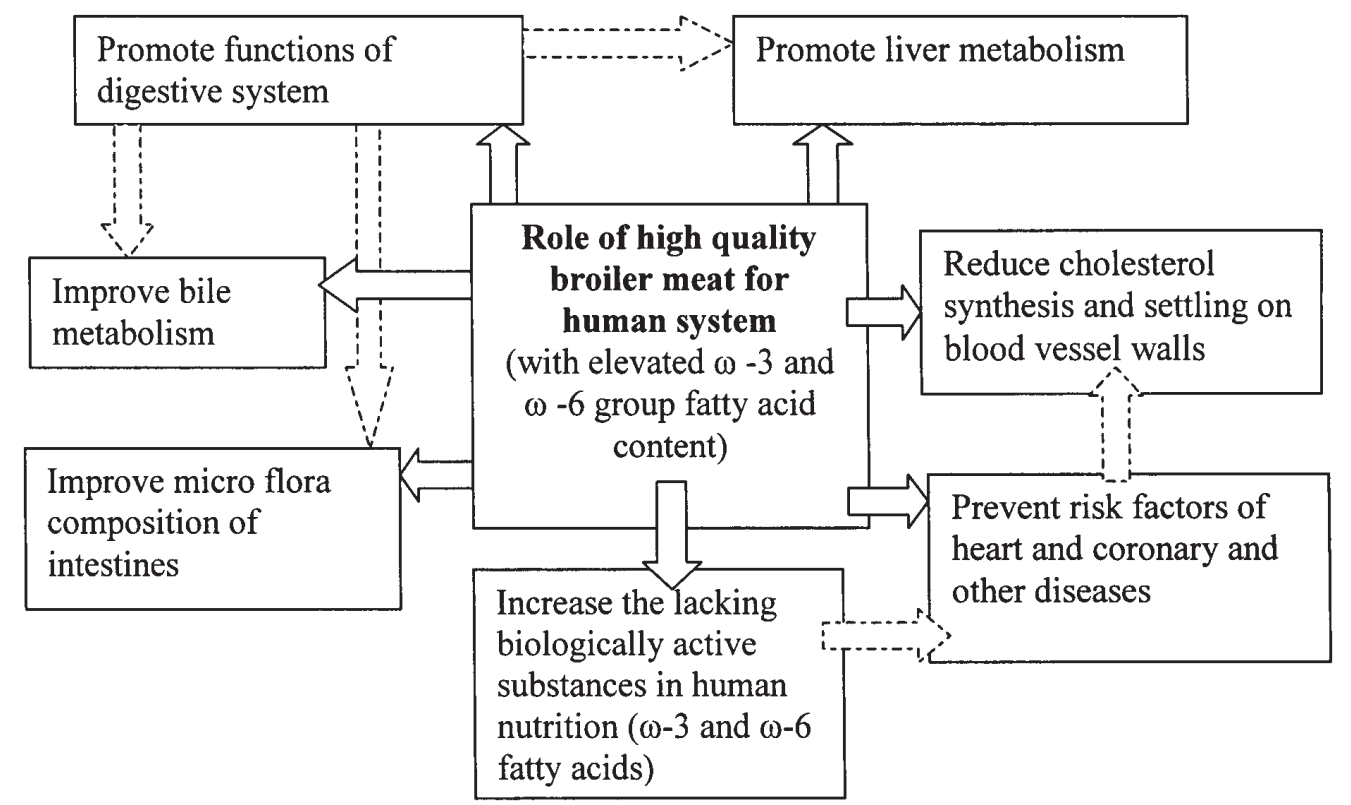

Fig. 1. Role of high quality broiler meat for human system.

Source: drawn by authors according to data of Tikk et al., 2001; Holub, 2002; Simpoulos, 2002; Anonymous, 2003 
AMOUNTS OF LINOLEIC AND LINOLENIC ACID AND THEIR RATIO IN FEED MATERIALS USED IN TRIAL

\begin{tabular}{l|c|c|c}
\hline \multicolumn{1}{c|}{ Indicator } & $\begin{array}{c}\text { Linolenic acid } \\
(\omega-3), \%\end{array}$ & $\begin{array}{c}\text { Linoleic acid } \\
(\omega-6), \%\end{array}$ & Ratio $\omega-6: \omega-3$ \\
\hline Linseed oil & 55.0 & 13.0 & $0.2: 1$ \\
Rapeseed oil & 9.0 & 20.0 & $2.8: 1$ \\
Soya been oil & 8.0 & 54.0 & $6.8: 1$ \\
Sunflower oil & 1.2 & 61.0 & $50.8: 1$ \\
\hline
\end{tabular}

Source: Cerina et al., 2010

ration: $2 \%$ soya bean oil $+1 \%$ rapeseed oil $+1 \%$ linseed oil. Relative to the control group, the level of linolenic acid was increased by $6.5 \%$. Our trials proved that addition of rapeseed and linseed oil sourced in Latvia and imported soya bean oil to the feed ration elevated the levels of the fatty acids linolenic acid ( $\omega-3)$ and linoleic acid ( $\omega-6)$ as well as caused a decrease of cholesterol in broiler meat, thus improving the broiler meat quality indicators.

\section{WILD ANIMALS AND ROMAN SNAIL MEAT AND ITS QUALITY}

Within the framework of National Research Programme "Innovative technologies for acquisition of high quality, safe and wholesome food products from genetically, physiologically and biochemically diverse raw materials of plant and animal origin" the Research Institute of Biotechnology and Veterinary Medicine "Sigra" carried out comparative testing of the biochemical composition and nutritional value of muscle tissue obtained from wild animals - red deer (Cervus elaphus), elks (Alces alces), roe deer (Capreolus capreolus) and agricultural animals: cross between Latvian Brown (LB) and Limousin (LI). The reason for including this this cross-breed in the trial was its supreme quality beef in Latvia.

The muscle tissue of the above wild animals tested contained on average $18.69-23.69 \%$ crude protein and $0.62-$ $0.29 \%$ crude fat. The muscle tissue of red deer and elk contained a higher amount of crude protein, 23.05-23.69\%. The lowest amount of crude protein $(18.61 \%)$ was found in the muscle tissue of roe deer. The highest amount of crude fat $(0.82 \%)$ was observed in elk muscle tissue, and the lowest $(0.62 \%)$ in red deer muscle tissue.

The cross-breed LB x LI muscle tissue contained on average $22.27 \%$ crude protein, which is by $0.81-1.39 \%$ lower than the crude protein content in elk and red deer muscle tissue. The amount of crude fat constituted $0.86 \%$, which was practically on the same level as that in red deer and elk meat.

The nutritive value of meat is characterised by the ratio of crude protein / crude fat amounts in muscle tissue and expressed as the so-called meat quality index. A higher the meat quality index is associated with a higher dietetic quality of meat. Red deer meat has the highest meat quality in- cross-breed meat (25.86).

Energy value of red deer, elk, roe-deer and beef breed cattle muscle tissue is similar, and in the range of 95.04-100.90 $\mathrm{kcal} / 100 \mathrm{~g}$.

The cholesterol level in muscle tissue of wild animals was in the range of $66.10-86.21 \mathrm{mg} \%: 66.10 \mathrm{mg} \%$, in elk muscle. $66.53 \mathrm{mg} \%$ in beef muscle and $68.97 \mathrm{mg} \%$ in roe deer muscle.

The proportion of $\omega-6$ fatty acids in the muscle tissue of wild animals analysed was in the range from $3.37-4.51 \%$, and $\omega$-3 fatty acids within the limits of $0.98-1.83 \%$, as calculated from total lipids. The muscle tissue of LB x LI cross-breed was distinguished by a higher proportion of both $\omega-6(4.12-6.07 \%)$ and $\omega-3(2.15-3.49 \%)$ fatty acids.

The content of carotenoids and vitamins $\mathrm{A}$ and $\mathrm{E}$ in meat of wild animals and the muscle tissue of beef cattle were very similar, and varied from $0.03-0.04 \mathrm{mg} / \mathrm{kg}$ for carotenoids, $0.02 \mathrm{mg} / \mathrm{kg}$ for vitamins A and $0.48 \mathrm{mg} / \mathrm{kg}$ for vitamins $\mathrm{E}$.

The nutritive value of the meat acquired from wild animals including red deer, elks and roe deer was higher than that of beef (LB x LI cross-breed). Consequently, game meat provides higher quality raw material for food intended for human consumption.

The cultivation of the Roman snail has recently expanded in Latvia, and it was necessary to conduct research on how to obtain raw material from Roman snail with high quality and excellent organoleptic features. Currently, more than 180 agricultural holdings in Latvia are involved in cultivation of the Roman snails. At the same time, snail meat is a little-known novel food in this country, and is offered mainly in restaurants as a delicacy. The Institute of Biotechnology and Veterinary Medicine "Sigra" of LUA set up and registered a trial holding for cultivation of the Roman snails and undertook studies in snail feeding and evaluation of the snail meat quality on the basis of its biochemical indicators. It was established that the meat of Roman snails cultivated in Latvia contains on average $13.2 \%$ protein, $1.8 \%$ fat and the highest percentage of poly-unsaturated $\omega-3$ and $\omega-6$ fatty acids of all types of meat. At the same time, the cholesterol level found in meat of the Roman snails cultivated in Latvia is a problem issue. Its content critically exceeds that found in meat of the wild snails found in this country. The reason for this gap is so far unknown, and requires further research. The levels of the amino acid oxyproline and tryptophan constitute accordingly $2.2 \mathrm{~g} / \mathrm{kg}$ and $2.4 \mathrm{~g} / \mathrm{kg}$ and their ratio in the snail meat is 0.9 , which indicates to a relatively high amount of connective tissue.

\section{MEANING OF GOOD PRAXIS AND HYGIENE IN MEAT PROCESSING}

Hygiene, cleanliness and the level of microbial contamination of animal carcasses is regulated by strict hygiene and 
veterinary inspection rules at all technological chain and crossing points of the carcass processing. Allowing shortcuts in execution of technological and hygiene rules at carcass, butchering and at the sales point increase risk of contamination by micro-organisms harmful to humans. The risk level is especially aggravated by an increase of the air temperature.

As established in research conducted by the Research Institute of Biotechnology and Veterinary Medicine "Sigra" of LUA (Jemeljanovs et al., 2006), the most common micro-organisms contaminating the surface of carcasses were from the genera Proteus, Staphylococcus and Micrococcus. The bacteria most frequently isolated from meat obtained from in-voluntarily culled animals were Escherichia coli (up to $20-40 \%$ cases), followed by Streptococcus spp. and Staphylococcus spp. (up to $18 \%$ of cases). On separate occasions, also Clostridium perfringens, Clostridium septicum and Clostridium corynae were isolated. In cases of serious inflammation processes and abscesses in various organs, caused by Clostridium oedematiens, we have found not only micro-organisms but also their spores. The contamination of beef and pork with Clostridium perfringens is a result of reduced disease-resistance of the animal over its lifetime, stress, non-observation of the animal welfare requirements and direct injury. Meat spoilage and multiplication of micro-organisms are influenced by environment temperature and especially moisture. The most rapid growth of microorganisms in meat occurs when the relative air moisture is higher than 90-95\%. The surface of carcass and meat harbours less microorganisms when the surface is covered by a dry crust (Raminšs, 1999). Deamination of amino acids in meat results in release of pure ammonia, which bonds with organic acids, forming an alkaline (salt) that causes the $\mathrm{pH}$ of meat to approach neutral (6.8-6.9). A neutral $\mathrm{pH}$ reaction is favourable for development of putrefaction microflora: Proteus spp., Pseudomonas spp. etc. A similar reaction is observed in meat acquired by killing tired or sick animals. During transportation of tired animals, in 30\% of cases altered microflora and unfavourable cocci are found in the intestines and internal organs. Meat toxicosis in humans occurs as a result of consuming meat of animals that have been tired out or slaughtered for involuntary culling. Due to low of resistance of the body, microorganisms invade the muscles and organs of such animals when they are still alive. In post-slaughter storage at temperature higher than $+3 \mathrm{oC}$, the formation of the microbe toxins is likely.

Use for human consumption of meat contaminated with relatively pathogenic or pathogenic micro-organisms, for example with bacteria of the genus Salmonella, is dangerous. Salmonella may be present in meat, and especially in its processed product: minced meat. The source of infection is sick domestic animals, poultry and their products, as well as rodents (mice and rats). Toxic infection can be caused also by Proteus mirabilis, Proteus vulgaris and Escherichia coli. Meat is contaminated with the above micro-organisms mainly during slaughter or due to failure to observe meat processing and storage hygiene rules. Contamination can occur also during skinning of game carcasses.

Staphylococci and streptococci can be found on the surface of carcasses in cases when the live animal has had purulent inflammations of tissue or organs.

Storing meat at temperature $0{ }^{\circ} \mathrm{C}$, the growth of microorganisms is slowed down, albeit not terminated. Therefore, after a certain period of time, irrespective of the temperature, the meat is subject to spoilage under any storage conditions. For a certain period of time, the micro flora in meat does not change in quantity and quality. This can by explained by drying off of meat, forming a thin crust on its surface, and by meat $\mathrm{pH}$ in the acidic value zone. The length if this phase depends on the level of initial microbial contamination of meat.

During slaughter in certified slaughterhouses, meat is practically not contaminated with microorganisms. During the chilling phase, growth of microorganisms is slowed down further, and upon freezing it is terminated. In this phase, the composition of microorganisms also undergoes changes. The number of mezophilic and thermophilic organisms is reduced down to $2-5 \%$ of the total number of microbes. Psychotropic microorganisms lose their multiplication ability already at temperature $-5{ }^{\circ} \mathrm{C}$ and lower, but some of them, e.g., Achromobacter spp. and Pseudomonas spp. still retain their multiplication ability also at this temperature. The maximum destruction of microorganisms occurs during slow freezing of meat down to $-6--12{ }^{\circ} \mathrm{C}$.

Repeated freezing and melting of meat lead to an increase of the amount of microorganisms on the surface of meat. Our studies demonstrate that repeated freezing and thawing of beef results in changes of its morphological composition: the cell membrane is destroyed and microbial contamination increases. Depending on the air temperature, the microbial contamination of meat, in comparison with the surface microbial contamination of freshly cut meat, increases by 2.7-7.4 times.

A goal of the research study "Research of the complex impact of genetic and welfare factors on changes in chemical, histological and microbiological indicators of bovine and pig meat" conducted by Research Institute of Biotechnology and Veterinary Medicine "Sigra", Latvia University of Agriculture, was to study morphological changes of bovine and pig meat under storage conditions. Histological examination of the muscle Longissimus lumborum of pig carcasses indicated formation of new muscular fibres amid normal muscle fibres side by side with fibre atrophy, in some animal groups. The formation of new fibres is connected with the start of pathologic processes, signalling interference with normal tissue development. In our opinion, this is a field of science that requires further investigation, especially from an etiological aspect. Further studies need to determine whether this is associated with pathogenic development triggered by cross breeding, underestimated breaches of the animal welfare requirements or other reasons. 
Identical changes had taken place after storage of the pig muscle tissue in vacuum packaging at $+2{ }^{\circ} \mathrm{C}-+5{ }^{\circ} \mathrm{C}$ for all types of cross-breeds. After 96 hours, destruction of separate fibres was observed as empty spaces between fibres, and their number continuously increased up to 20 days. This study also needs to be continued.

After storage of bovine meat at $+2{ }^{\circ} \mathrm{C}-+5{ }^{\circ} \mathrm{C}$, destroyed muscle fibres could be found only after 15 days of storage.

\section{CONCLUSIONS}

1. Over the last twenty years, the production of beef, pork and poultry meat has rapidly declined in Latvia.

2. Meat obtained from bovine beef breeds has the potential for becoming a consumer favoured product in Latvia. It contains wholesome proteins and fatty acids in appropriate amounts and ratios for humans, a low cholesterol level, and good organoleptic and culinary properties.

3. Pig carcass has a higher proportion of fat tissue than muscle tissue. In comparison with the chemical composition of bovine muscle tissue, pig meat stands out for its energy value and fat content. The amino acids tryptophan, oxiproline and their ratios indicate meat quality. The tryptophan/oxiproline ratio in pig meat (7.2) is higher than in bovine meat (3-4), which indicates of relatively higher nutritive value of the former. Animal breeding and nutrition should be targeted at obtaining the maximum amount of intramuscular fat, i.e., 2.5-3.0\%, retaining optimum fibrousness of pig meat.

4. The feeding of different combinations of locally produced rapeseed and linseed oil and imported sunflower oil to broilers results in increase of the fatty acids necessary for humans - linolenic acid ( $\omega-3)$ and linoleic acid $(\omega-6)$ and decrease of cholesterol, thus improving the meat quality indicators.

5. The nutritive value of meat obtained from wild animals, including red deer, elks and roe deer is higher than that obtained from the cross breed between Latvian Brown and Limousin breeds. Meat of the above game animals serves as high value raw material for meat products for human consumption.

6. The studies undertaken in Latvia regarding Roman snail meat is a novelty development targeted at obtaining a food product with excellent taste qualities.

7. To obtain safe, wholesome and high quality meat for human consumption, strict observation of hygiene rules is required at all stages of acquisition of the animal origin raw materials for producing food for human consumption.

8. To ensure use of high quality animal origin raw materials for the production of food for human consumption, it is necessary to continue morphological, chemical and biochemical studies of carcass tissue of meat animals. The use of indicators is needed to improve animal feeding and genetic material.

\section{REFERENCES}

Anonymous (2010). AVEC Annual Report 2010. Belgium: Association of Poultry Processors and Poultry Trade in the EU Countries. ASBL. 53 pp. http://www.avec-poultry.eu/Default.aspx ?ID=6379.

Anonymous (2011a). Agriculture in the European Union: Statistical and economic information.

http://ec.europa.eu/agriculture/statistics/agricultural/2011/index_en.htm (last accessed 11 June 2012).

Anonymous (2011b). AVEC Annual Report 2011. Belgium: Association of Poultry Processors and Poultry Trade in the EU Countries, ASBL. 53 pp. http://www.avec-poultry.eu/Default.aspx ?ID=6736.

Anonymous (2003). Population nutrient intake goals for preventing diet-related chronic diseases. In: Diet, nutrition and the prevention of chronic diseases: Report of a joint WHO/FAO expert consultation (916, pp. 54-60). Genova: WHO.

Anonymous (2012a). Agriculture Data. Eurostat.

http://epp.eurostat.ec.europa.eu/portal/page/portal/statistics/search_database (last accessed 11 June 2012).

Anonymous (2012b). Database Livestock Primary. Faostat. http://faostat.fao.org/site/569/DesktopDefault.aspx?PageID=569\#ancor (last accessed 11 June 2012).

Cerina, S., Krastina, V., Vitina, I.I. (2011). Production and expenses of innovative composition broiler chicken meat in Latvia. Agron. Res., 9(2), $383-388$.

Gramatina, I., Rakcejeva, T., Silina, L., Jemeljanovs, A. (2011). Comparison of venison and beef chemical composition. In: 57th International Congress of Meat Science and Technology "Global Challenges to Production, Processing and Consumption of Meat”, 7-12 August 2011. Ghent, Belgium: Belgian Association of Meat Science and Technology.

Holub, B.J. (2002). Clinical nutrition: 4. Omega-3 fatty acids in cardiovascular carve. Can. Medical Assoc. J., 166(5), 608-615.

Jansons, I., Jemeljanovs, A. (2010). The influence of phytogenic additives on pig productivity, carcases and meat quality. Gyvulininkyste , 56, 45-54.

Jansons, I., Jemeljanovs, A., Konosonoka, I.H., Sterna, V., Lujane, B. (2011). The influence of organic acid additive, phytoadditive and complex of organic acid additive phytoadditive on pig productivity, meat quality. Agron. Res., 9(2), 389-394.

Jemeljanovs, A. (1999). Nepiesārṇotas un augstvērtīgas pārtikas ražošanas zinātniskais nodrošinājums [The scientific guarantee of non polluted and high value food production]. Grām.: Latvijas lauksaimniecības zinātniskie pamati: zinātniska monogrāfija (7.1., 7.4.-7.19., 7.162.-7.164. 1pp.). Strīksis, V. (red.). [Jelgava]: LLU (in Latvian).

Jemeḷjanovs, A., Nudiens, J., Duḷbinskis, J., Šterna, V. (2006). Bioloǵiskajā lauksaimniecībā ražotās gaḷas kvalitāte un iespējamais mikrobiālais piesārṇojums [Meat quality and possible microbial pollution in organic agriculture]. Grām.: Lauksaimniecības dzīvnieki un to produkcija biologískajā lauksaimniecībā: monogrāfija (128.-140. 1pp.). Jemeljanovs, A. (galv. red.). Sigulda: [LLU Biotehnoloǵijas un veterinārmedicinas zinātniskais institūts „Sigra”] (in Latvian).

Jemeljanovs, A., Zitare, I., Miculis, J., Ikauniece, D., Proskina, L., Zutis, J. (2009). Deer health status and meat quality in Latvian deer farms. Chem. Technol., 3(52), 90-92.

Magdelaine, P., Spiess, M.P., Valceschnini, E. (2008). Poultry Meat Consumption Trends in Europe. World's Poultry Sci. J., 64(1), 53-63.

Ramiņš, E. (1999). Krustošana un hibridizācija cūkkopībā [Crossing and hybridization in pig breeding]. Grām.: Latvijas lauksaimniecības zinātniskie pamati: zinātniska monogrāfija (7.121.-7.126.lpp.). Strīkis, V. (galv. red.). [Jelgava]: LLU (in Latvian). 
Simopoulos, A.P. (2002). Omega-3 fatty acids in inflammation and autoimmune diseases. J. Amer. College Nutr., 21, 495-505.

Strazdina, V., Jemeljanovs, A., Šterna, V. (2012). Staltbriežu (Cervus elaphus) gaḷas ḳīmiskā sastāva izvērtējums Latvijā [The chemical assessment of deer (Cervus elaphus) meat in Latvia]. Grām.: LLU Lauksaimniecības fakultātes, Latvijas Agronomu biedrības un Latvijas Lauksaimniecības un meža zinātñu akadèmijas organizētās zinātniski praktiskās konferences raksti: Zinātne Latvijas lauksaimniecības nākotnei: pārtika, lopbarība, škiedra un enerğija, 2012. g. 23.-24. februārī (219.-223. lpp.). Jelgava: LLU.

Strazdina, V., Jemeljanovs, A., Sterna, V., Antone, U. (2010). Evaluation of fatty acid composition of deer (Cervus elaphus) meat produced on Latvia farms and wildlife. Gyvulininkyste , 56, 37-44.

Strazdina, V., Jemeljanovs, A., Sterna, V., Vjazevica, V. (2011). Evaluation of protein composition of game meat in Latvian farms and wildlife. Agron. Res., 9(2), 469-472.

Tikk, H., Viigimaa, M., Tikk, V., Hämmal J. (2001). The effect of consumption of omega fatty acid enriched quail eggs on blood characteristic in hypercholesterolemic men. In: Proceedings of the IX Baltic Poultry Conference, 14 September 2001 (pp. 12-14). Tartu.
Vītina, I., Krastina, V., Proškina, L., Lujāne, B., Liepina, S. (2010). Comparison of venison and beef quality. In: Baltic Animal Breeding XV Conference, 31 May - 1 June 2010 (pp. 147-150). Rīga: State Agency "Agricultural Data Centre".

Warris, P. (2000). Meat Science. Oxon: CAB Publishing. 310 pp.

Warris, P.D., Brown, S.N., Franklin, J.G., Kestin, J.C. (1990). The thickness and quality of backfat in various pig breeds and their relationship to intramuscular fat and the setting of joints from the carcass. Meat Science, 28, $21-29$.

Zariņš, Z., Neimane, L. (2002). Uztura mācība [Nutrition Study]. Rīga: Rasa ABC. 416 lpp. (in Latvian).

Цериня С.В., Емельянов А.В., Витиня И.В., Крастиня В.Э. (2010) Влияние содержания линолевой кислоты в рационе птиц на уровень холестерина в мясе бройлеров и яйцах кур [Linoleic acid influence on cholesterol level in broilers chicken meat and laying hens egg]. В кн.: Сборник трудов первой международной научно-практической конферениии "Высокие технологии, фундаментальные и прикладные исследования в физиологии и медицине”, 23-26 ноября 2010 (Т. 4, с. 366-372). г. Санкт-Петербург, Россия: Институт физиологии им. И. П. Павлова РАН, Институт цитологии РАН (in Russian).

Received 15 June 2012

\section{LATVIJAS IEDZİVOTĀJU UZTURĀ LIETOJAMĀS GALAAS VĒRTĒJUMS}

Pēdējā desmitgadē liellopu, cūkgal̦as un putnu gạ̦as ražošana Latvijā strauji samazinājusies. Latvijas iedzīvotāju gaḷas patēriņš gadā ir aptuveni $60 \mathrm{~kg}$. Tradicionāli vairāk tiek patērēta cūkgaḷa, mazāk — izmaksu ziṇā dārgā liellopu gaḷa. Latvijā tiek ievesta un pārdota lētāka gaḷa no dažādām Eiropas Savienības valstīm. LLU Biotehnoloǵijas un veterinārmedicīnas zinātniskajā institūtā „Sigra” tiek veikts nozīmīgs zinātniskais darbs gaḷas kvalitātes, patērētājam veselīgas un drošas dzīvnieku izcelsmes pārtikas izejvielas ieguves izpētē. Gaḷs škirnes liellopu ganāmpulki ir ḷoti atšḳirīgi gan pēc dzīvniekiem, gan arī pēc realizējamās produkcijas kvalitātes. Liellopu gaḷā ir vidēji 5,4-8,13\% $\omega-3$ un $12,97-16,27 \% \omega-6$. $\omega-6$ un $\omega-3$ kavē holesterīna nogulsnēšanos asinsvadu sieniņās. Gaḷas šķirnes liellopu gaḷa satur daudz pilnvērtīgu olbaltumvielu, taukskābju, kas ir organismam nepieciešamos daudzumos un attiecībās, relatīvi zemu holesterīna līmeni — vidēji 77 mg\%, labas kulinārās smaržas un garšas īpašības. Turpinās pētījumi par dažādu cūku škiinnu gaḷas kvalitāti, tās ietekmējošiem faktoriem un par patērētāja prasībām atbilstošas produkcijas ieguvi. Plaši pētījumi turpinās broileru gaḷas kvalitātes izpētē, izstrādājot tās jaunas kvalitātes ieguvi. Izvērtēta tiek arī savvaḷas dzīvnieku gaḷas nozīme cilvēku uzturā, izvērtēti tās ieguves procesa higiēnas jautājumi. Sakarā ar gliemežu audzēšanas attīstību Latvijā uzsākts gliemežu gaḷas izvērtējums un nozīmes izpēte cilvēku uzturā. 